\title{
THE COMMUNITY NUTRITION GARDEN (POKIMAS) IN THE KINGDOM COMMUNITY OF BGBJ, BEKASI, WEST JAVA
}

\author{
Wardina HUMAYRAH ${ }^{1 *}$, Laila FEBRINA ${ }^{2}$ and Megah STEFANI ${ }^{3}$ \\ ${ }^{1,3}$ Nutrition Study Program, Sahid University, Jakarta, Indonesia \\ ${ }^{2}$ Environmental Engineering Study Program, Sahid University, Jakarta, Indonesia \\ *wardina_humayrah@usahid.ac.id
}

\begin{abstract}
The Kingdom of BGBJ or "Kingdom of the Seeds of Bantar Gebang" is a community within the Bantar Gebang Final Waste Disposal Site (TPSA) area which has an effect on the quality of public health and the environment of the area due to the lack of access to sanitation and the lack of reforestation land. On the other hand, the economic conditions and the low education of the parents make the residents around the community limited in accessing household food sources that are not in accordance with balanced nutrition. The general objective of this Community Partnership Program activity is the establishment of a Pilot The Community Nutrition Garden (POKIMAS) in the Kingdom of BGBJ, Bantar Gebang, Bekasi, West Java as a motivator for the surrounding community to participate in POKIMAS in each household. The method used in this activity adapts to the situation and conditions of the Covid 19 pandemic, training is carried out online and complete education modules are provided which will be given to all targets so that they are easy to learn independently at home. The PKM team will provide TOT (Training of Trainers) online to the core team of the BGBJ Royal Community and then the Core team is responsible for providing training to 10 POKIMAS target participants. The results and benefits that have been achieved include: increased knowledge of how to create and the importance of POKIMAS; the creation of 16 simple nutrition gardens managed by households around BGBJ which previously did not exist. Initial target of 10 POKIMAS gardens; as well as the addition of 8 participants that have nutrition gardens around the BGBJ pilot project. The program that is still running with the commitment of the BGBJ community is expected to consume vegetables and fruit from POKIMAS that are made independently by participants.
\end{abstract}

Keywords: balanced nutrition, bantar gebang, nutrition garden, vegetable and fruit

\section{BACKGROUND}

Bantar Gebang is one of the largest Solid Waste Disposal Sites in Indonesia, located in Bantar Gebang District, Bekasi City, West Java Province, Indonesia which has been operating since 1989. Bantar Gebang TPST receives $16,000 \mathrm{~m} 3$ of $20,000 \mathrm{~m} 3$ of resident waste per day DKI Jakarta in 2011. And the amount of waste is increasing from year to year at the end of the 2015 period every month as much as $214,972.08$ tons/month. The sent waste is usually in the form of dry waste (such as plastic, paper and cardboard) and wet waste (vegetables and other household waste) (Satrio, Syafalni dan Paston Sidauruk, 2014 dan Sitio Raston, 2017). The existence of waste around the Bantar Gebang TPST has more or less integrated into every line of life of the surrounding community so that it significantly affects the quality and cost of public health. Diseases commonly found there include: upper respiratory tract infections (ARI), diarrhea, and malaria (Sitio Raston, 2017).

The people around the Bantar Gebang TPST are people who are mostly in the lower middle economic class. The community around the TPST also has a low level of concern for the importance of education so it is difficult to rise from poverty. Most parents in the Bantar Gebang TPST area employ their children as garbage collectors and earn money to support their families after they return home from school. Uncertain income from scavenging livelihoods and lack of skills and education reduce job opportunities and improve the family's economy (Mulyadi Didi, 2016).

The name of this community is "The Kingdom of BGBJ" or commonly referred to as "Kingdom of the seeds of Bantar Gebang" which is a community in the Bantar Gebang Final Waste Disposal Site (TPSA) area. This community was initiated by a native woman born in Bantar Gebang named Risa Boenard. The beginning of the birth of BGBJ was motivated by a sense of concern for the future of the surrounding community (TPSA) who are still in the cycle of poverty with low economic and educational levels with a livelihood as scavengers or garbage collectors. This community believes that children and youth are the seeds for a positive future at the TPA.

The name "BGBJ" originated from a philosophy of "Seeds" (in English pronunciation which is read Bi, Ji, Bi, Jei). This community focuses on programs for children and youth around TPSA Bantar Gebang with the philosophy of seeds or seeds that can thrive with love and proper care until they become strong trees. This community provides education, training, assistance, food, and creativity programs for underprivileged children and youth around TPST. The program is carried out at the BGBJ studio free of charge and is expected to change the mindset of parents around the Bantar Gebang TPSA so that they continue to support their children's education so that they are free from the cycle of poverty.

In addition, the BGBJ Kingdom also opened a special hostel for international tourists for trash and community tourism (Trash and Social Tourism) around the Bantar Gebang TPSA. The BGBJ empire is a unique community asset and is starting to expand into productive economic communities. This community also opens volunteers from local youth to become BGBJ tour guides to welcome tourists from various foreign countries in introducing the 
positive side of tourism in the area around TPSA Bantar Gebang. This community also provides an art studio to produce souvenirs made from used wood from around the Bantar Gebang TPSA to be sold to tourists staying at the hostel.

Based on data from the BGBJ local community, it shows that there are around 3000 families living around the Bantar Gebang Integrated Waste Management Site (TPST), who work as scavengers. Children in Bantar Gebang generally do not get a proper education. The pungent smell due to waste pollution around the landfill, not only affects the health but also the mental condition of the people around Bantar Gebang. Many of the residents lack confidence when they have to appear in social circles outside Bantar Gebang because of the unpleasant smell that sticks to their clothes due to the garbage around them. Carrying out a mission to realize the dreams of children in the Bantar Gebang TPST area, this local community is present as a forum.

In the future, parents of children and youth around the BGBJ Royal Community also need to be encouraged to participate in this community education program so that they can jointly support the improvement of the living standards of the families of the surrounding community. The condition of the houses of residents around this community is alarming, especially those whose main livelihood is as scavengers who have minimal access to proper sanitation and reforestation. Greening around the residents' environment can minimize the pungent smell of garbage. On the other hand, the low education of parents makes residents around the community access household food sources as they are available in local warungs. The surrounding community is vulnerable to diseases that arise due to waste and do not understand properly the benefits of implementing balanced nutrition for family members. The concept of balanced nutrition includes the implementation of clean and healthy living behavior as well as the fulfillment of balanced nutritional intake such as consumption of vegetables and fruit for the immune system to reduce the risk of contracting infectious diseases (Bornard Resa, 2019 dan Mohammad A, Madanijah S, 2015).

In general, the goal to be achieved in this Community Partnership Program activity is the establishment of a Pilot Community Nutrition Garden in the Kingdom of BGBJ Community, Bantar Gebang, Bekasi, West Java as a motivator and activator for the surrounding community to participate in POKIMAS in each household. The POKIMAS Nutrition Garden program is based on previous research in the Jebres area, Surakarta in 2014 which succeeded in providing positive impacts and benefits for the community, especially regarding clean and healthy living behavior related to the habit of eating vegetables and fruit, the benefits of economic aspects, food security and participation. Public. Previous studies recommended this program to be applied and implemented in other areas (Kurniasih DE, Joko A, 2018 dan Kurniasih DE, Kusumaningsih R, 2014). This POKIMAS activity targets the establishment of 1 pilot community nutrition garden in the Kingdom of BGBJ Community and 10 households in the surrounding community who can also implement a simple home nutrition garden.

\section{METHOD}

Due to the Covid 19 pandemic, training is conducted online and complete educational modules are provided which will be given to all targets so that they are easy to learn independently at home. The PKM team will provide TOT (Training of Trainers) online to the core team of the BGBJ Royal Community and then the Core team is responsible for providing training to 10 POKIMAS target participants. There all two phases of this program with the following details:

First Stage (Preparation)

At this stage it is divided into 4 activities, namely:

1. Coordination with the implementation team

The implementation team consisted of 3 lecturers, 2 support staff held an online meeting about preparation for starting the program and the necessary tools.

2. Online coordination with the Kingdom of BGBJ Community

Online meeting with the Founder of the Kingdom of BGBJ Community regarding possible facilities and infrastructure, implementation schedule, participant targets, and team preparation in the field.

3. Delivery of Pre-Test Questionnaire to BGBJ

Bundle printing and delivery of Pre-Test questionnaires to the BGBJ Team to be given to 10 POKIMAS household participants as baseline data before starting the TOT and also the program. Questionnaires were given and collected by all core BGBJ Teams and sent back to the PKM Team to be processed as initial data measuring the needs and abilities of the surrounding community which became the basis for making material modules.

4. Preparation of mentoring materials and supporting tools Making Modules in the form of Compact Disks (CD), with 3 series of materials including: Balanced Nutrition Education \& POKIMAS, Making Takakura Fertilizers, and Making Home Vertical Gardens. While the main supporting equipment is for materials and tools prepared for the manufacture of modules and demonstration gardens during the TOT.

\section{Second Stage (Implementation of Activities)}

The stages of implementing these activities and mentoring are carried out for 4 times online training in accordance with 4 series of modules. However, this implementation activity was postponed until the pandemic period subsided with an agreement with the BGBJ Team starting in early October 2020. The series of implementation program schemes can be seen in Figure 6 below. 


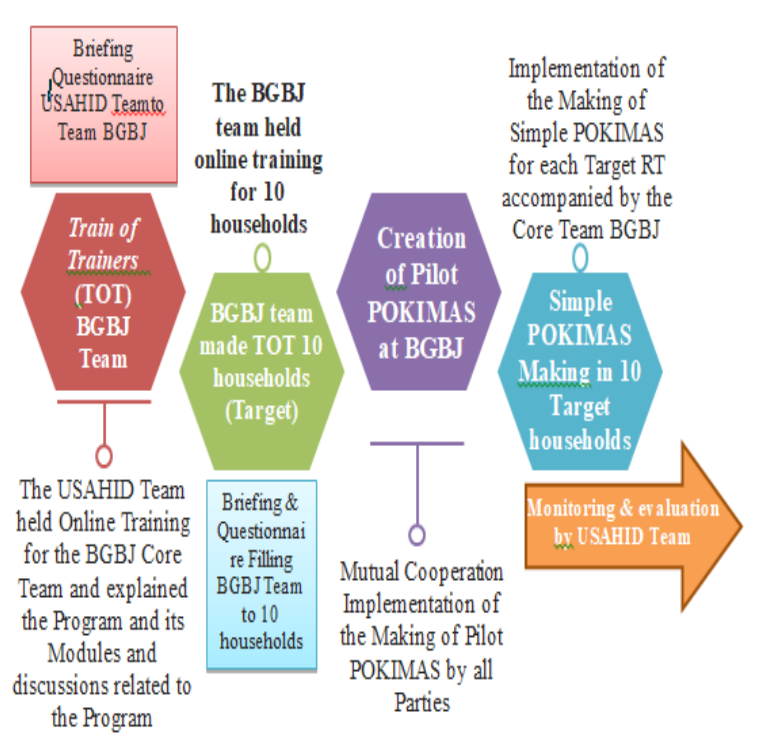

Figure 1. Schematic of the second stage (implementation)

\section{RESULTS AND DISCUSSION}

The POKIMAS Community Nutrition Garden program is based on previous research in the Jebres area, Surakarta in 2014 which succeeded in providing positive impacts and benefits for the community, especially regarding clean and healthy living behavior related to the habit of eating vegetables and fruit, the benefits of economic aspects, food security and participation. Public. Previous studies recommended this program to be applied and implemented in other areas (Kurniasih DE, Joko A, 2018 dan Kurniasih DE, Kusumaningsih R, 2014).

This POKIMAS activity targets the establishment of 1 pilot community nutrition garden in the Kingdom of BGBJ Community and 10 households in the surrounding community who can also implement a simple home nutrition garden. This activity consists of 3 main programs: Providing education and motivation of resources, community nutrition garden program (POKIMAS), Assistance and program sustainability.

This program have been achieved include: increased knowledge of how to create and the importance of Home Vertical Gardens; the creation of 16 simple nutrition gardens managed by households around BGBJ which previously did not exist. Initial target of 10 nutrition gardens; as well as the addition of 8 additional households that have nutrition gardens around the BGBJ pilot POKIMAS gardens. The initial target is 1 nutrition garden within 6 months of the program.

Providing education and motivation of resources represented through Train of Trainers (TOT) BGBJ Team. The initial training activity began with an online Training of Trainer (TOT) for the BGBJ initiator, Resa Boenard, on October 6, 2020. This activity consisted of discussing 3 video modules on POKIMAS (Community Nutrition Garden Program) Embodiment of Balanced Nutrition; Compost Making Technique with Takakura Method; and Verticulture-Based Home Gardening Techniques. This video module is neatly and simply designed to be easy to implement in the community. This video was made in the form of a compact disk (CD) and can also be accessed freely on the official YouTube page of the Nutrition Study Program, Faculty of Food and Health Technology, USAHID by the general public.

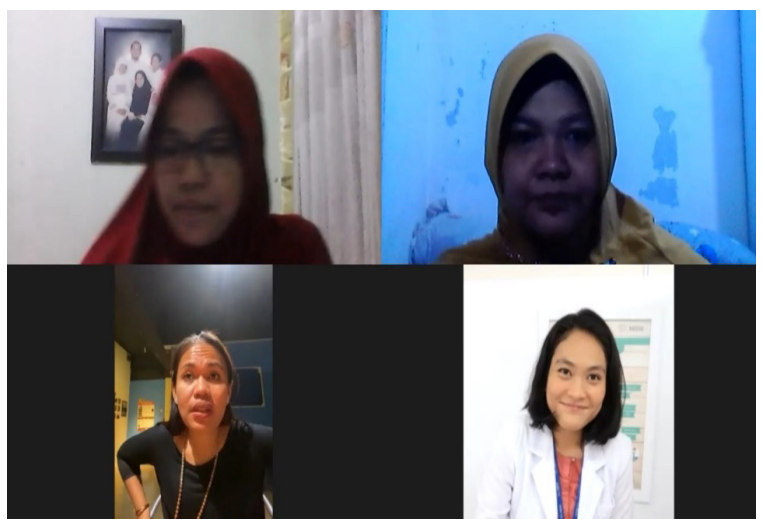

Figure 2. TOT Coordination for BGBJ Team

The purpose of this training module is for the community to continuously understand the technique of making compost and simple vertical home gardens so that they can produce vegetables and fruit so that it is expected to change the behavior of eating fruit and vegetables to meet the family's nutritional intake. Furthermore, the BGBJ Team as a partner is obliged to carry out TOT to surrounding households to conduct online or offline training so that they can transfer knowledge and skills and invite them to participate in POKIMAS (Community Nutrition Garden Program) so that the sustainability of the program can run sustainably.

Due to pandemi situation there are limitation for doing community nutrition garden program (POKIMAS) directly, the difficulty of coordination for the implementation and the limited time for face-to-face meetings, the USAHID Team in Citayam made a pilot POKIMAS in Citayam in collaboration with Verticulture Practitioners. This homebased verticulture nutrition garden is also the material exemplified in the video module.

The handover of the Verticulture Nutritional Garden Pilot Unit was carried out directly during a visit to Bantar Gebang by the USAHID PKM Team through the Forum Group Discussion (FGD) activity. This activity was welcomed by Resa Boenard as the PKM partner who manages BGBJ. This FGD activity followed the health protocol starting with the distribution of masks to all participants before starting. Most of the FGD participants were housewives and their children, who were the forerunners of implementing home nutrition gardens to fulfill the family's vegetable and fruit needs.

The USAHID team provided direct socialization to the community about the importance of the Community Nutrition Garden Program which was initiated by a demonstration of the Vegetable and Fruit Garden which was handed over to the BGBJ Team. Vegetable and fruit plants given as a home verticulture garden model are kale, spinach, tomatoes, chili, passion fruit, kecombrang, etc. 


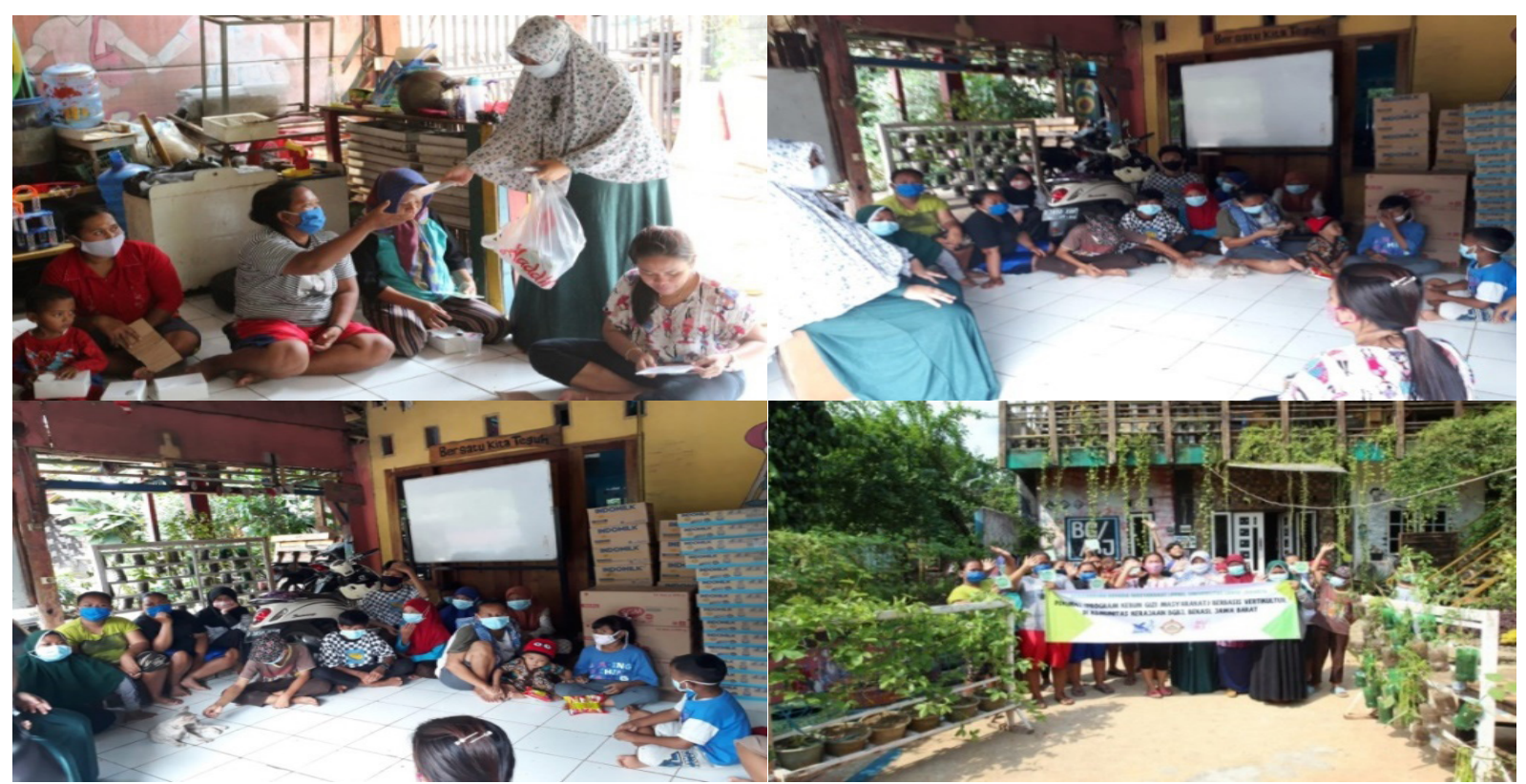

Figure 3. FGD activity with the BGBJ Community

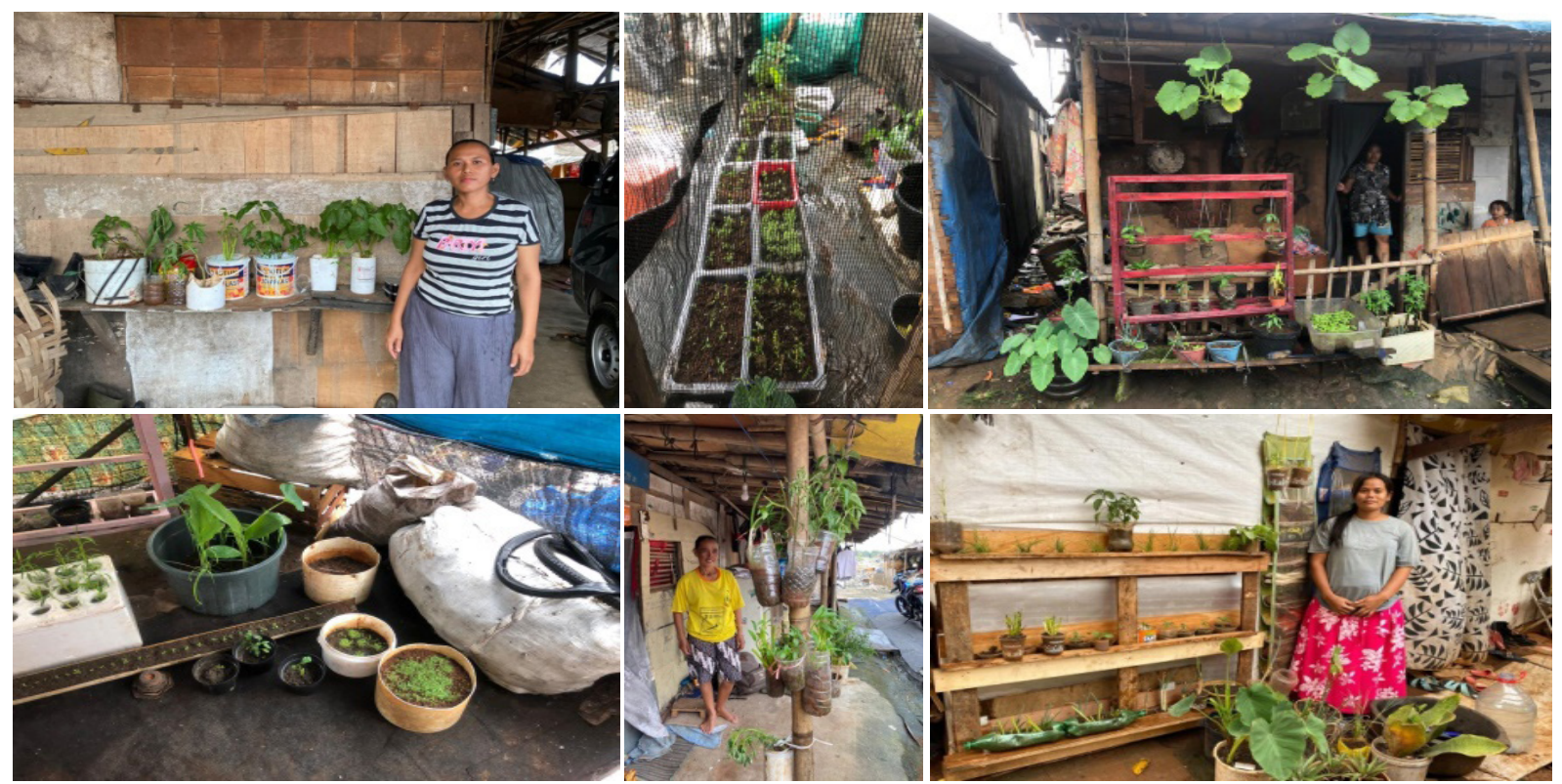

Figure 4. The simple POKIMAS making in 10 target households

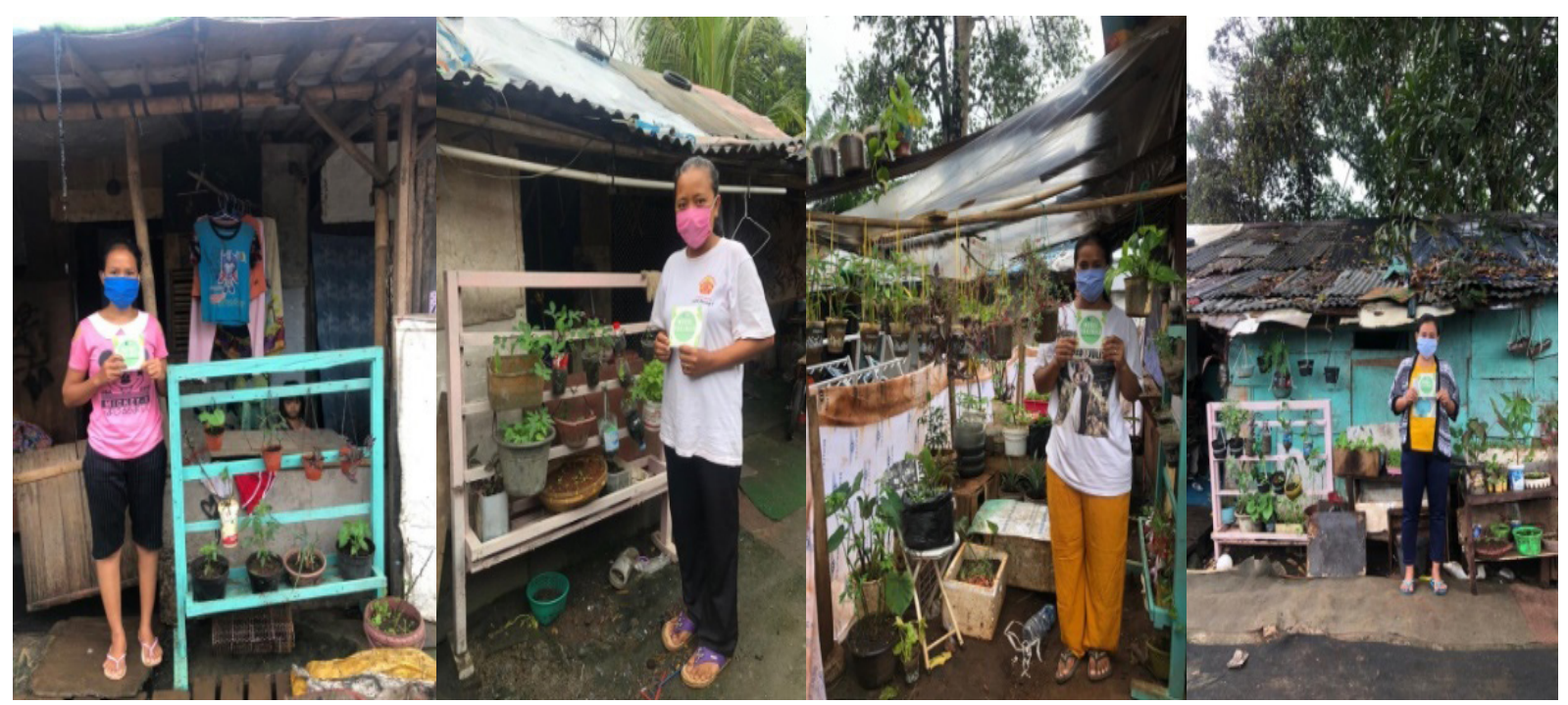

Figure 5. Assistance and program sustainability 
After the FGD activity, the BGBJ Team followed up the activity by conducting a direct TOT in November 2020 to initiate the community to create a simple verticulture garden as a source of vegetables and fruit for the family and community. This TOT activity was carried out directly by discussing and discussing the preparation of materials and tools as well as the implementation plan for making POKIMAS activities in each of the target households. At least 10 households were found who were interested in participating in POKIMAS, most of which were housewives who had committed to participate in program activities.

The making of POKIMAS not long after the TOT conducted by the BGBJ Team to the target households. Initially, only 10 targeted households were targeted, but in its implementation many people were interested so that 16 households were successfully active in the program. This activity was warmly welcomed by the local community, before POKIMAS most of the housewives around Bantar Gebang had difficulty accessing fruit and vegetables due to economic factors. Generally, the people there are scavengers, so to get vegetables and fruit they usually take from the remnants of supermarket waste that comes to the TPST. Most of the program participants were also creative not only with wooden shelves as in the exact example, but some used bamboo, used paint containers, and used goods that were easy to find around the TPST and living areas.

Monitoring and evaluation carried out by the USAHID team is not only direct but also communicates through video calls and WhatsApp text messages as well as online meetings via zoom. This monitoring and evaluation is carried out every 2 weeks by sending videos and photos of the verticulture nutrition gardens of the program participants. At the time of monitoring and evaluation, there were 8 additional households that also started to grow vegetables and fruits at home vertically. Most of the vegetables produced and consumed by the participants were kale, chilies, and mustard greens. Meanwhile, the passion fruit distributed has begun to bear fruit and can be enjoyed by the community around BGBJ.

\section{CONCLUSION}

Coordination between the implementing team went well for the implementation agreement to adjust the situation and condition of the target community during the pandemic. The program went well, judging by the commitment of the target community who participated in the program, exceeding the initial target. The program that is still running with the commitment of the BGBJ community is expected to have a positive long-term impact on the food security of the community around the Bantar Gebang TPST, especially in consuming vegetables and fruit from home verticulture gardens that are made independently by the program participants. There needs to be other comprehensive programs related to the development of home nutrition garden products that are not only consumed but can be produced more into products that can increase the income of the people around the Bantar Gebang TPST, Bekasi.

\section{ACKNOWLEDGEMENT}

First and foremost, praises and thanks to the God, the Almighty, for His showers of blessings throughout this program work to complete the research successfully. We would like to express the gratitude to Ministry of Education, Culture, Research and Technology, Republic of Indonesia, for giving the grant funding to do this program achieved. We also thanks for leader of BGBJ Resa Boenard and the society surround Bantar Gebang, Bekasi for the warm acceptances and good cooperation through this program came true.

\section{REFERENCES}

Boenard Resa. (2019). Seputar Kerajaan BGBJ. Wawancara langsung 12 Agustus 2019, Komunitas Kerajaan BGBJ, Bantar Gebang, Bekasi, Jawa Barat

Kurniasih Dwi Endah, Joko Adianto. (2018). Kebun gizi sebagai strategi berbasis masyarakat untuk memenuhi kebutuhan konsumsi. BKM Journal of Community Medicine and Public Health, Volume 34 No.2, Halaman 93-97.

Kurniasih Dwi Endah, Kusumaningsih, R. (2014). Pemanfaatan Lahan sebagai Pendukung Program Pemenuhan Gizi Masyarakat Laporan Kajian Best Practice Kebun Gizi Mandiri Pemenang MDGs Award 2013 Dusun Karet Pleret Bantul Yogyakarta. Cita Sehat Foundation Vol 1, Bandung.

Mohammad A, Madanijah S. (2015). Konsumsi buah dan sayur anak usia sekolah dasar di Bogor. Jurnal Gizi dan Pangan, Volume 10: (1).

Mulyadi Didi. (2016). Mengembangkan kepedulian akan pentingnya pendidikan untuk meningkatkan kesejahteraan masyarakat pemulung di tpa bantar gebang. Prosiding Seminar Nasional dan Gelar Produk UMM, tanggal 17-18 Oktober 2016.

Satrio, Syafalni dan Paston Sidauruk. (2014). Studi Karakteristik Air Tanah Dangkal Sekitar TPST Bantar Gebang, Bekasi, dengan Metode Sumur Tunggal dan Ganda. Jurnal Ilmiah Aplikasi Isotop dan Radiasi, Vol.10(1), 1 - 10.

Sitio Raston. (2017). Pengaruh Jumlah Sampah Masuk Bantargebang terhadap Biaya Kesehatan Masyarakat Ciketingudik dan Sumurbatu. Jurnal Aplikasi Manajemen, Ekonomi dan Bisnis, Vol. 2 (1), Oktober 2017, ISSN 2541-1438; E-ISSN 25500783, diterbitkan oleh STIM Lasharan Jaya. 